\title{
Infaunal recruitment patterns in soft bottom habitats of the Patos Lagoon estuary, southern Brazil: influence of Chasmagnathus granulata (Brachyura, Grapsidae) disturbance
}

\author{
Leonardo Cruz da Rosa $^{1,2} \&$ Carlos Emílio Bemvenuti ${ }^{1}$
}

\author{
1. Laboratório de Ecologia de Invertebrados Bentônicos, Departamento de Oceanografia, Fundação Universidade Federal de Rio \\ Grande (FURG), Caixa Postal 474, 96201-900 Rio Grande, RS, Brazil. \\ 2. Programa de Pós-graduação em Oceanografia Biológica, FURG. (cielcr@furg.br)
}

\begin{abstract}
A comparative study of the infaunal recruitment patterns among disturbed surface sediment mounds around Chasmagnathus granulata Dana, 1851 burrows and undisturbed adjacent sediments was done in two intertidal soft bottom habitats (an upper and a lower mudflat zone) in an estuarine inlet of Patos Lagoon, southern Brazil. The most abundant infaunal organisms were recruits of the polychaete Laeonereis acuta Treadwell, 1923 and of the tanaid Kalliapseudes schubartii Mañé-Garzón, 1949. The densities of these species did not differ significantly between upper and lower mudflat habitats. These species showed lower densities around crab burrows than in adjacent areas, where differences in sediment characteristics were observed as well. The results indicate that $C$. granulata disturbances may play an important role in regulating the soft bottom benthic community by controlling infaunal recruitment in the estuarine intertidal mudflats of the Patos Lagoon.
\end{abstract}

KEYWORDS. Burrowing crab, biological disturbances, infaunal recruitment, intertidal habitats, Patos Lagoon.

\section{INTRODUCTION}

Factors that are known to cause mortality of recent settlers in soft-sediments, thus affecting organism distribution and abundance, include physical and biological disturbances (WoOdin, 1991; ÓlaFsSON et al., 1994; Gosselin \& Qian, 1997; Hunt \& SCHEIBLING, 1997). Predation is the best-documented source of early postsettlement mortality (Hunt \& Scheibling, 1997). Bioturbation caused by species of great motility, such as birds, shrimp, crabs, and fish, also affects the structure and dynamics of the soft bottom communities (Brenchley, 1981; Ólafsson et al., 1994; Hunt \& SCHEIBLING, 1997).

The burrowing crab Chasmagnathus granulata Dana, 1851 is one of the most abundant macroinvertebrates in the SW Atlantic estuaries (BoschI, 1964; CAPITOLI et al., 1978; D'InCAO et al., 1990, 1992; Bemvenuti, 1997; Iribarne et al., 1997). In the Patos Lagoon estuary, this crab is commonly observed inhabiting salt marshes dominated by Spartina alterniflora Loiseleur, 1807 (Monocotyledoneae, Gramineae) and adjacent mudflats (CAPITOLI et al., 1978; Bemvenuti, 1997), reaching densities up to 98 ind. $\mathrm{m}^{-2}$ (D'InCAO et al., 1992). These crabs excavate and maintain semi-permanent open burrows, removing large amounts of sediment $\left(5.9 \mathrm{Kg} \mathrm{m}^{-2} \mathrm{day}^{-1}\right)$ during feeding and burrow maintenance, forming a surface mound around burrows (IRIBARNE et al., 1997). This reworking, besides affecting sediment characteristics (IRIBARNe et al., 1997; BOTTO \& IRIBARNE, 1999; 2000) seems also to affect the distribution of other benthic organisms (BotTo \& IRIBARNE, 1999).

In spite of its behavior, abundance and extensive distribution, little information is available about the effects of this crab on the structure of the benthic community in the intertidal areas of the Patos Lagoon estuary. Studies performed in other regions have not evaluated their effects on macrofaunal recruitment (IRIBARNE et al., 1997; BOTTO \& IRIBARNE, 1999). The aim of the present study is to compare the infaunal recruitment pattern among disturbed sediment mounds around $C$. granulata burrows and undisturbed adjacent sediments in two intertidal soft bottom habitats (an upper and a lower mudflat zone) in an estuarine inlet of Patos Lagoon.

\section{MATERIAL AND METHODS}

The study was performed in January/2000 (summer) in an area located near the east margin of Pólvora Island, Patos Lagoon, southern Brazil (fig. 1). Two habitats were selected along the intertidal area: (1) an upper mudflat zone and (2) a lower mudflat zone. The mean density of crab burrows in these habitats was 34 ( \pm $3.5)$ and $14( \pm 2.2)$ burrows $\mathrm{m}^{-2}$, respectively.

In each habitat nine samples were taken at each of two locations: in disturbed sediment mounds around crab burrows and in undisturbed adjacent areas distant approximately $30 \mathrm{~cm}$ from the burrow. The samples were collected with a corer of $2.6 \mathrm{~cm}$ inner diameter. The first 2 $\mathrm{cm}$ of the collected material were preserved with formalin (4\%) and stained with the vital stain Bengal Rose. Abiotic parameters such as $\mathrm{pH}$ and potential redox (Eh) were measured with an electronic meter. Surface sediment samples (from the first $2 \mathrm{~cm}$ ) were collected in order to determine the granulometry and organic matter content.

At the laboratory, the samples were washed in a series of sieves with apertures of 500, 250, 125 and $63 \mu \mathrm{m}$. The use of different mesh sizes, smaller than that traditionally used $(0.5 \mathrm{~mm})$ for macrofaunal studies (Holme \& McIntyre, 1984), enabled sampling of the 


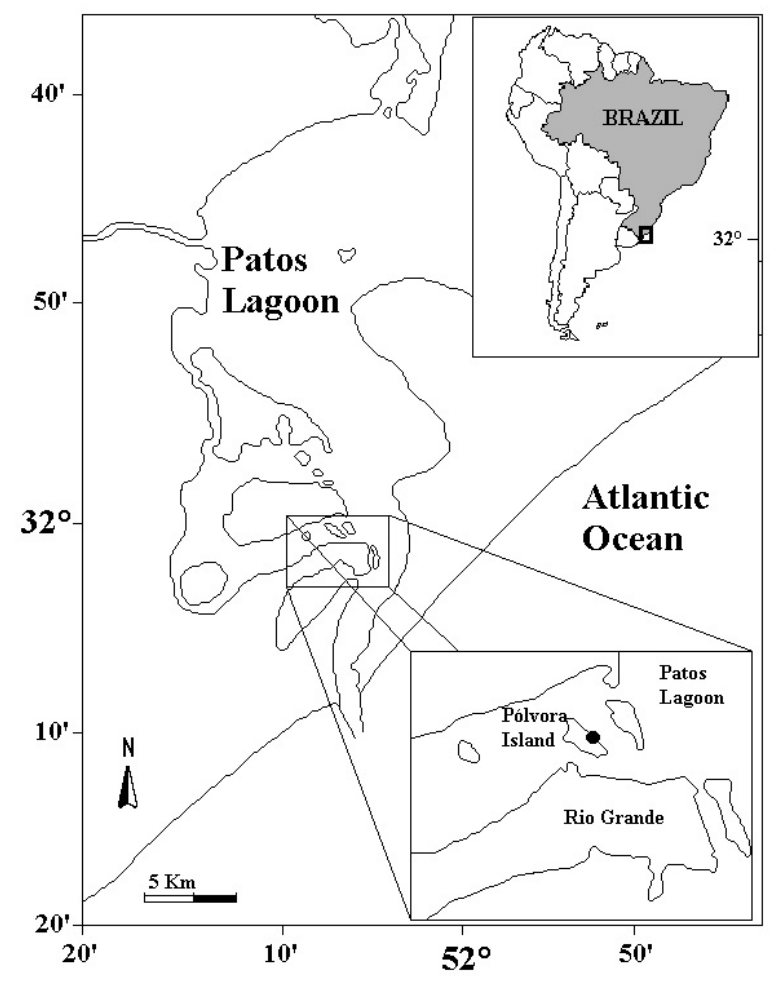

Fig. 1. Estuarine region of Patos Lagoon, Rio Grande do Sul, Brazil, indicating the study area $(\bullet)$

recent settlers. Mesh size was used to determine the size classes of infaunal organisms during their recruitment period. Infaunal size class was defined by mesh size in which the individuals were retained. The retained material in each mesh was sorted, identified and quantified with a stereoscopic microscope.

Granulometric data were obtained through sieving and pipette analysis. Dried sub-samples were then burned at $550^{\circ} \mathrm{C}$ for $60 \mathrm{~min}$ in order to determine organic content through weight loss (Suguio, 1973).

Two-way ANOVA was used to test for differences in both abiotic parameters and biological data (i.e., each infaunal size class as dependent variable) among habitats (upper and lower mudflat zones) and locations (undisturbed adjacent areas and sediment mound). All data were tested for normality (Kolmogorov-Smirnov test) and homogeneity of variances (Cochran test and standard deviations-means plots) prior to their use in statistical tests (UNDERWOOD, 1997). Data were transformed to assure variance homogeneity and distribution normality when necessary. In cases in which the ANOVA result was significant ( $\mathrm{p}<0.05)$, the Tukey's HSD post hoc test was applied (UNDERWOOD, 1997).

\section{RESULTS}

All abiotic parameters varied significantly between the habitats (tab. I). Sediment composition ranged from moderately sorted fine sand in the lower mudflat to very poorly sorted finest sand in the upper mudflat zone. Fine fractions and organic matter increase from lower to upper mudflat zone, while redox potential (Eh) and $\mathrm{pH}$ decreased (tab. I). Comparing among locations only fine fractions

Table I. Summary of Two-way ANOVA evaluating difference in abiotic parameters among habitats (upper vs. lower mudflat zone) and locations (crab mounds vs. undisturbed adjacent areas) (*, analysis performed on $\sqrt{(\mathrm{x})}$ transformed data; $*$, analysis on arcsine of $\sqrt{(\mathrm{x})}$ transformed data; AA, undisturbed adjacent areas; Df, degrees of freedom; Lw, lower mudflat; M, sediment mounds; MS, mean square; Up, upper mudflat).

\begin{tabular}{|c|c|c|c|c|c|}
\hline Source of variation & Df & MS & $F$-value & $p$-level & Tukey test \\
\hline \multicolumn{6}{|l|}{ Mean grain size $(\phi)^{*}$} \\
\hline Habitat & 1 & 0.135 & 92.407 & $<0.001$ & $\mathrm{Up}>\mathrm{Lw}$ \\
\hline Location & 1 & 0.002 & 1.059 & 0.316 & \\
\hline Habitat $v s$. Location & 1 & $<0.001$ & 0.105 & 0.749 & \\
\hline Residual & 20 & 0.001 & & & \\
\hline \multicolumn{6}{|l|}{ Sorting* } \\
\hline Habitat & 1 & 1.045 & 130.819 & $<0.001$ & $\mathrm{Up}>\mathrm{Lw}$ \\
\hline Location & 1 & 0.034 & 4.271 & 0.052 & \\
\hline Habitat $v s$. Location & 1 & 0.004 & 0.517 & 0.481 & \\
\hline Residual & 20 & 0.008 & & & \\
\hline \multicolumn{6}{|l|}{ Fines $(\%)^{\#}$} \\
\hline Habitat & 1 & 0.229 & 1450.785 & $<0.001$ & $\mathrm{Up}>\mathrm{Lw}$ \\
\hline Location & 1 & 0.012 & 7.826 & 0.011 & $\mathrm{AA}>\mathrm{M}$ \\
\hline Habitat $v s$. Location & 1 & $<0.001$ & 0.178 & 0.677 & \\
\hline Residual & 20 & 0.001 & & & \\
\hline \multicolumn{6}{|l|}{ Organic matter content (\%) } \\
\hline Habitat & 1 & 0.388 & 15.387 & 0.001 & $\mathrm{Up}>\mathrm{Lw}$ \\
\hline Location & 1 & $<0.001$ & $<0.001$ & 0.99 & \\
\hline Habitat $v s$. Location & 1 & 0.014 & 0.537 & 0.472 & \\
\hline Residual & 20 & 0.025 & & & \\
\hline \multicolumn{6}{|l|}{$\mathrm{pH}$} \\
\hline Habitat & 1 & 9.972 & 83.531 & $<0.001$ & $\mathrm{Lw}>\mathrm{Up}$ \\
\hline Location & 1 & 0.063 & 0.528 & 0.476 & \\
\hline Habitat vs. Location & 1 & 0.215 & 1.799 & 0.195 & \\
\hline Residual & 20 & 0.119 & & & \\
\hline \multicolumn{6}{|l|}{ Potential redox $(\mathrm{mV})$} \\
\hline Habitat & 1 & 70850.6 & 28.887 & $<0.001$ & $\mathrm{Lw}>\mathrm{Up}$ \\
\hline Location & 1 & 3174.01 & 1.294 & 0.269 & \\
\hline Habitat $v s$. Location & 1 & 2688.17 & 1.096 & 0.308 & \\
\hline Residual & 20 & 2452.65 & & & \\
\hline
\end{tabular}


varied significantly, with higher values in adjacent areas than on sediment mounds (tab. I). Habitats vs. locations interactions were not significant for any parameter and mean values of each parameter are given in tab. II.

The most abundant infaunal organisms were the polychaete Laeonereis acuta Treadwell, 1923 (Nereidae) and the tanaid Kalliapseudes schubartii Mañé-Garzón, 1949 (Kalliapseudidae), which corresponded to 95\% of total fauna. The polychaetes Heteromastus similis Southern, 1921 (Capitellidae) and Nephtys fluviatilis Monro, 1937 (Nephtyidae), the gastropod Heleobia australis Marcus \& Marcus, 1963 (Hydrobiidae), the pelecypod Erodona mactroides Bosc, 1802 (Erodonidae) and the cumacean Diastylis sympterigiae Bacescu \& Queiroz, 1985 (Diastylidae) were less abundant and/or frequent organisms and were not included in the analysis or discussion.

Most L. acuta recruits (i.e., 57.5\%) had size classes equal to $125 \mu \mathrm{m}$, whereas $36.5 \%$ and $6 \%$ of individuals had 250 and $500 \mu \mathrm{m}$ size classes, respectively. For $K$. schubartii, $14 \%, 55 \%$ and $31 \%$ of recruits had 125,250 and $500 \mu \mathrm{m}$ size classes, respectively.

ANOVA results showed that differences in the densities of all size classes were not significant among habitats for both species (tab. III). Also, significant differences were found among locations for both species (tab. III). In both habitats, all L. acuta size classes had higher densities at adjacent areas than on sediment mounds (figs. 2, 3). For K. schubartii, higher densities were also found at adjacent areas than on mounds, except for individuals of $125 \mu \mathrm{m}$ size class (figs. 4, 5).

\section{DISCUSSION}

The results showed that the polychaete Laeonereis acuta and the tanaid Kalliapseudes schubartii recruit equally in both mudflat habitats, in spite of physicalchemical differences. Both species showed lower

Table II. Mean values and standard deviation (in parenthesis) of abiotic parameters measured in both locations at each habitat.

\begin{tabular}{|c|c|c|c|c|}
\hline \multirow{2}{*}{ Parameter } & \multicolumn{2}{|c|}{ Lower mudflat } & \multicolumn{2}{|c|}{ Upper mudflat } \\
\hline & Adj. Area & Mounds & Adj. Area & Mounds \\
\hline Mean Grain size $(\phi)$ & $2.87( \pm 0.01)$ & $2.83( \pm 0.04)$ & $3.42( \pm 0.23)$ & $3.34( \pm 0.16)$ \\
\hline Sorting & $0.67( \pm 0.04)$ & $0.60( \pm 0.04)$ & $1.62( \pm 0.37)$ & $1.36( \pm 0.25)$ \\
\hline Fines $(\%)$ & $7.10( \pm 0.67)$ & $5.29( \pm 1.14)$ & $20.89( \pm 5.62)$ & $16.68( \pm 2.39)$ \\
\hline Organic Matter (\%) & $0.29( \pm 0.07)$ & $0.34( \pm 0.16)$ & $0.60( \pm 0.25)$ & $0.55( \pm 0.10)$ \\
\hline $\mathrm{pH}$ & $7.10( \pm 0.15)$ & $6.97( \pm 0.35)$ & $5.97( \pm 0.34)$ & $5.64( \pm 0.33)$ \\
\hline Potential Redox (mV) & $-97( \pm 39.1)$ & $-125( \pm 62.1)$ & $-216( \pm 21.5)$ & $-228( \pm 56.6)$ \\
\hline
\end{tabular}

Table III. Summary of Two-way ANOVA evaluating differences in densities of infaunal size classes among habitats (upper vs. lower mudflat zone) and locations (crab mounds vs. undisturbed adjacent areas). Analysis performed on log ( $\mathrm{x}+1)$ transformed data. (Df, degrees of freedom; MS, mean square).

\begin{tabular}{|c|c|c|c|c|}
\hline Source of variation & Df & MS & $F$-value & $p$-level \\
\hline \multicolumn{5}{|l|}{ L. acuta $(125 \mu \mathrm{m})$} \\
\hline Habitat & 1 & 0.003 & 0.009 & 0.926 \\
\hline Location & 1 & 18.758 & 55.036 & $<0.001$ \\
\hline Habitat vs. Location & 1 & 1.412 & 4.141 & 0.050 \\
\hline Residual & 32 & 0.341 & & \\
\hline \multicolumn{5}{|l|}{ L. acuta $(250 \mu \mathrm{m})$} \\
\hline Habitat & 1 & 2.128 & 2.841 & 0.101 \\
\hline Location & 1 & 12.007 & 30.235 & $<0.001$ \\
\hline Habitat vs. Location & 1 & 0.242 & 0.609 & 0.441 \\
\hline \multirow{2}{*}{\multicolumn{5}{|c|}{ L. acuta $(500 \mu \mathrm{m})$}} \\
\hline & & & & \\
\hline Habitat & 1 & 0.028 & 0.137 & 0.714 \\
\hline Location & 1 & 2.495 & 12.170 & 0.001 \\
\hline Habitat vs. Location & 1 & 0.028 & 0.137 & 0.714 \\
\hline \multirow{2}{*}{\multicolumn{5}{|c|}{ K. schubartii $(125 \mu \mathrm{m})$}} \\
\hline & & & & \\
\hline Habitat & 1 & 0.031 & 0.211 & 0.649 \\
\hline Location & 1 & 0.031 & 0.211 & 0.649 \\
\hline Habitat vs. Location & 1 & 0.031 & 0.211 & 0.649 \\
\hline Residual & 32 & 0.148 & & \\
\hline \multicolumn{5}{|l|}{ K. schubartii $(250 \mu \mathrm{m})$} \\
\hline Habitat & 1 & 0.000 & 0.000 & 0.988 \\
\hline Location & 1 & 2.467 & 7.358 & 0.011 \\
\hline Habitat vs. Location & 1 & 0.000 & 0.000 & 0.988 \\
\hline Residual & 32 & 0.335 & & \\
\hline \multicolumn{5}{|l|}{ K. schubartii $(500 \mu \mathrm{m})$} \\
\hline Habitat & 1 & 0.031 & 0.211 & 0.649 \\
\hline Location & 1 & 1.526 & 10.316 & 0.003 \\
\hline Habitat $v s$. Location & 1 & 0.031 & 0.211 & 0.649 \\
\hline Residual & 32 & 0.148 & & \\
\hline
\end{tabular}


densities around crab burrows than in adjacent areas, thus suggesting a possible effect of the burrowing crab Chasmagnathus granulata on recruitment of infaunal organisms. Also, there were found differences in sediment properties among locations (i.e., lower fines proportion at sediment mounds than at adjacent areas).

Both infaunal species are commonly found in high densities in shallow water flats of the Patos Lagoon estuary (BEMVENUTI, 1997). As the temperature increases in late spring and early summer, the reproductive activity of infaunal species increases, resulting in dense recruitment in the estuarine inlets of the region (BEMVENUTI, 1987; 1997). During the recruitment period these species are also subjected to strong populational control by epifaunal macropredators (BEMVENUTI, 1987; 1997).

The burrowing crab $C$. granulata is a depositfeeder but, despite deposit feeders can indirectly ingest newly settled organisms (Woodin, 1976), did not exist evidence that this crab selectively preys upon infaunal organisms (D'INCAO et al., 1990; IRIBARNE et al., 1997; BotTo \& IRIBARNE, 1999). The effects of this crab on infaunal recruitment are mainly related to an intense sediment disturbance because of the burrowing activities.

The crabs activities increase the sediment instability and thus inhibit the settlement and/or persistence of infaunal recruits. Studies have shown that interactions with burrowing organisms affect recruitment rates (PETERSON, 1982; Peterson \& Black, 1993; ÓlafsSON et al., 1994; Thrush et al., 1996), limiting infaunal density through bioturbation (BRENCHLEy, 1981; Posey, 1986; Posey et al., 1991). BRENCHLEY (1981) experimentally demonstrated that the addition of macroinfaunal or macroepifaunal organisms affects the infauna, resulting in lower densities, especially of tube-building organisms. This effect was also related to increasing sediment instability promoted by burrowing activities.

The crab disturbance caused by continuous sediment deposition around the burrows could also increase mortality of infaunal recruits by suffocation. Alterations of sediment properties by crab activities could indirectly affect infaunal recruitment. Both L. acuta and $K$. schubartii are tube builders and need fine sedimentary fractions for constructing their tubes (BEMVENUTI, 1997; Rosa-Filho \& Bemvenuti, 1998). Consequently, undisturbed adjacent areas, which have more fine proportions than sediment mounds, are more suitable for their recruitment.

BotTo \& IRIBARNE (1999) evaluated the $C$. granulata effects on macrofauna community in a coastal lagoon of Argentina. These authors verified that L. acuta densities greatly decreased during summer inside crab beds. The decrease of polychaete densities was attributed to increase of crab activity during summer period, although their field experiments (i.e., the use of exclusion cages) failed to detect significant effects. The undetected effects in BOTTO \& IRIBARNE's (1999) experiments, where the faunal samples were washed in a $500 \mu \mathrm{m}$ mesh size, are probably related to methodological problems.

The present results demonstrated that most $L$. acuta recruits (> 50\%) were retained in $125 \mu \mathrm{m}$ mesh size and only $6 \%$ in $500 \mu \mathrm{m}$. Therefore, the utilization of an $500 \mu \mathrm{m}$ mesh size seems inappropriate for evaluating the

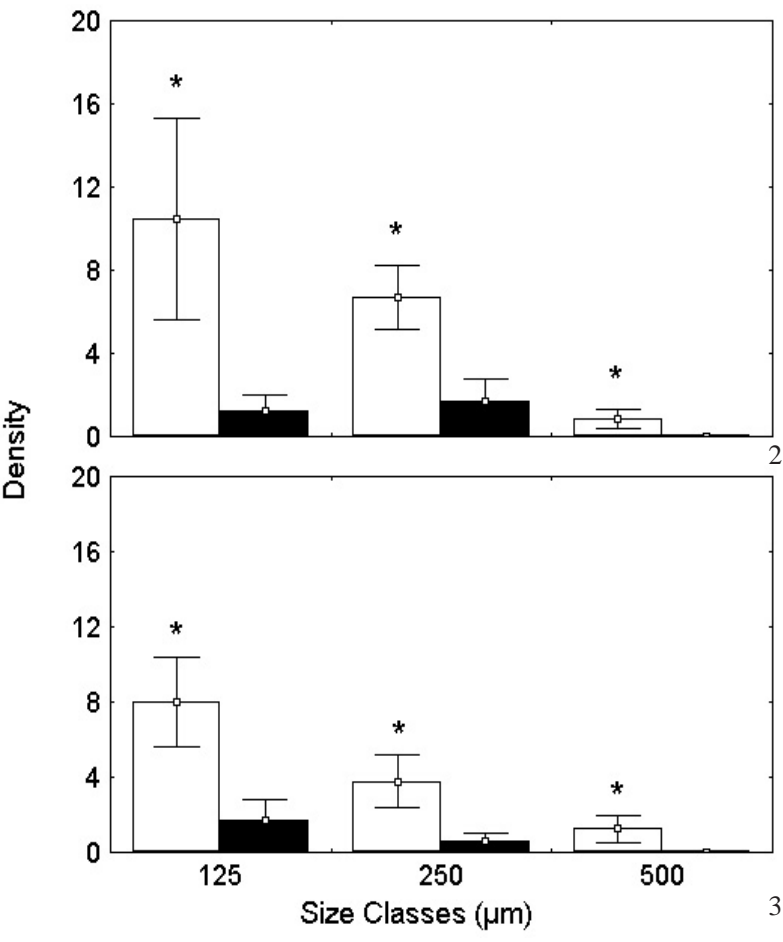

Figs. 2, 3. Mean density (ind. $10 \mathrm{~cm}^{-2}$ ) of the different size classes of the polychaete Laeonereis acuta in undisturbed adjacent areas (empty bars) and crab mounds (closed bars) at: 2, lower mudflat; 3 , upper mudflat zone. Error bars are \pm 1 SD. Asterisks indicate significant differences $(p<0.05)$ among locations on the same size class determinated by Tukey post hoc test.

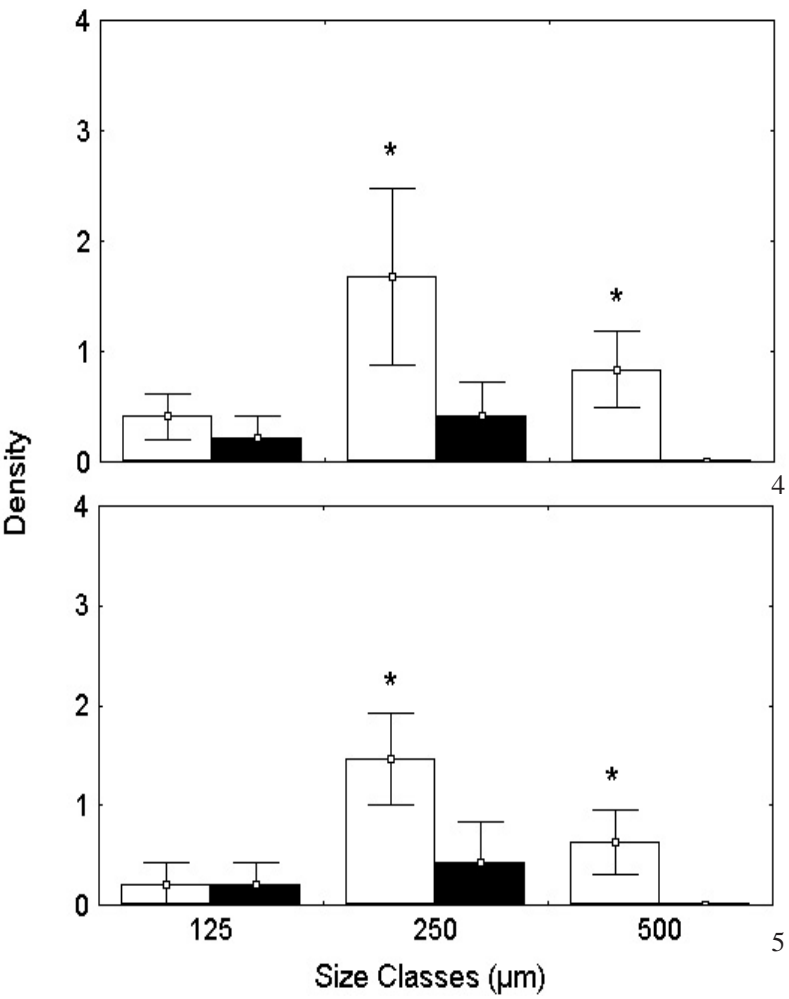

Figs. 4, 5. Mean density (ind. $10 \mathrm{~cm}^{-2}$ ) of the different size classes of the tanaid Kalliapseudes schubartii in adjacent areas (empty bars) and crab mounds (closed bars) at: 4, lower mudflat; 5, upper mudflat zone. Error bars are $\pm 1 \mathrm{SD}$. Asterisks indicate significant differences $(p<0.05)$ among locations on the same size class determinated by Tukey post hoc test. 
effects of burrowing crabs on infauna during the recruitment period. In this way, lower polychaete densities observed in summer by BOTTO \& IRIBARNE (1999) may be consequence of crab effects on infaunal recruitment. We suggest that the burrowing crab $C$. granulata may play an important role in regulating local soft bottom benthic communities by controlling infaunal recruitment in the estuarine intertidal mudflats of the Patos Lagoon.

Acknowledgments. To Mr. Nilton A. Abreu for help at the Laboratório de Ecologia de Invertebrados Bentônicos (FURG). The study received financial support from CAPES and CNPq (PELD Project, Proc. \# 520188/98-5).

\section{REFERENCES}

Bemvenuti, C. E. 1987. Predation effects on a benthic community in estuarine soft sediments. Atlântica, Rio Grande, 9:5-32.

1997. Benthic invertebrates. In: Seeliger, U.; Odebrecht, C. \& Castello, J. P. eds. Subtropical convergence environments. The coast and sea in the southwestern Atlantic. Berlin, Springer-Verlag. p.43-46.

Boschi, E. E. 1964. Los crustáceos decápodos Brachyura del litoral bonarense (Republica Argentina). Boletin del Instituto de Biología Marina, Mar del Plata, 6:1-76.

Botto, F. \& Iribarne, O. 1999. Effects of the burrowing crab Chasmagnathus granulata (Dana) on the benthic community of a SW Atlantic coastal lagoon. Journal of Experimental Marine Biology and Ecology, Amsterdam, 241:263-284.

2000. Contrasting effects of two burrowing crabs (Chasmagnathus granulata and Uca uruguayensis) on sediment composition and transport in estuarine environments. Estuarine, Coastal and Shelf Science, London, 51:141-151.

Brenchley, G. A. 1981. Disturbance and community structure: an experimental study of bioturbation in marine softbottom environments. Journal of Marine Research, New Haven, 39:767-790.

Capitoli, R.; Bemvenuti, C. E. \& Gianuca, N. M. 1978. Estudos de ecologia bentônica na região estuarial da Lagoa dos Patos. I. As comunidades bentônicas. Atlântica, Rio Grande, 3:5-22.

D'Incao, F.; Ruffino, M. L. et al. 1992. Responses of Chasmagnathus granulata Dana (Decapoda: Grapsidae) to salt-marsh environmental variations. Journal of Experimental Marine Biology and Ecology, Amsterdam, 161:179-188

D'Incao, F.; Silva, K. G. et al. 1990. Hábito alimentar do caranguejo Chasmagnathus granulata Dana, 1851 na barra do Rio Grande, RS (Decapoda: Grapsidae). Atlântica, Rio Grande, 12:85-93.

Gosselin, L. A. \& Qian, P. Y. 1997. Juvenile mortality in benthic marine invertebrates. Marine Ecology Progress Series, Oldendorf, 146:265-282.

Holme, N. A. \& McIntyre, A. D. 1984. Methods for the study of marine benthos. 2. ed. Oxford, Blackwell Scient. $387 \mathrm{p}$.

Hunt, H. L. \& Scheibling, R. E. 1997. Role of early postsettlement mortality in recruitment of benthic marine invertebrates. Marine Ecology Progress Series, Oldendorf, 155:269-301.

Iribarne, O.; Bortolus, A. \& Botto, F. 1997. Between-habitat differences in burrow characteristics and trophic modes in the southwestern Atlantic burrowing crab Chasmagnathus granulata. Marine Ecology Progress Series, Oldendorf, 155:132-145.

Ólafsson, E. B.; Peterson, C. H. \& Ambrose, W. G., Jr. 1994. Does recruitment limitation structure populations and communities of macro-invertebrates in marine softsediments: the relative significance of pre- and possettlement processes. Oceanography and Marine Biology. An Annual Review, Aberdeen, 32:65-109.

Peterson, C. H. 1982. The importance of predation and intraand interspecific competition in the population biology of two infaunal suspension-feeding bivalves, Protothaca staminea and Chione undatella. Ecological Monographs, Tempe, 52:437-475.

Peterson, C. H. \& Black, R. 1993. Experimental tests of the advantages and disadvantages of high density for two coexisting cockles in a Southern Ocean lagoon. Journal of Animal Ecology, London, 62:614-633.

Posey, M. H. 1986. Changes in a benthic community associated with dense beds of a burrowing deposit-feeder, Callianassa californiensis. Marine Ecology Progress Series, Oldendorf, 31:15-22.

Posey, M. H.; Dumbauld, B. R. \& Armstrong, D. A. 1991. Effects of a burrowing mud shrimp, Upogebia pugettensis (Dana), on abundance of macro-infauna. Journal of Experimental Marine Biology and Ecology, Amsterdam, 148:283-294.

Rosa-Filho, J. S. \& Bemvenuti, C. E. 1998. O sedimento como fator limitante para a distribuição de Kalliapseudes schubartii Mañé-Garzón, 1949 (Crustacea, Tanaidacea) em fundos moles estuarinos. Nauplius, Rio Grande, 6:119127.

Suguio, K. 1973. Introdução à sedimentologia. São Paulo, EDUSP. 317p.

Thrush, S. F.; Hewitt, J. E. et al. 1996. Adult-juvenile interactions of infaunal bivalves: contrasting outcomes in different habitats. Marine Ecology Progress Series, Oldendorf, 132:83-92.

Underwood, A. J. 1997. Experiments in Ecology - their logical design and interpretation using Analysis of Variance. Cambridge, Cambridge University. 504p.

Woodin, S. A. 1976. Adult-larval interactions in dense infaunal assemblages: patterns of abundance. Journal of Marine Research, New Haven, 34:25-41.

1991. Recruitment of infauna: positive or negative cues? American Zoologist, Seattle, 31:797-807.

Recebido em maio de 2003. Aceito em maio de 2004. ISSN 0073-4721 